\title{
Lipophilicity of Peptide Anions: An Experimental Data Set for Lipophilicity Calculations
}

\author{
Rubin Gulaboski and Fritz Scholz* \\ Ernst-Moritz-Arndt-Universität Greifswald, Institut für Chemie und Biochemie, Soldmannstrasse 23, \\ D-17489 Greifswald, Germany
}

Received: February 14, 2003; In Final Form: April 4, 2003

\begin{abstract}
For the first time, the standard Gibbs energies of the transfer of peptide anions from aqueous solution to nitrobenzene were determined with the help of electrochemical measurements. These systematic studies clearly show that the lipohilicity contributions of single amino acid residues to the overall lipohilicity of a peptide anion strongly depend on the position of the amino acid in the backbone of the peptide. Therefore, additive models to calculate the overall lipophilicity of a peptide cannot provide very precise data. The present study is a plea for the experimental establishment of a data set that takes into account the individual nature of an amino acid residue and its position in a peptide.
\end{abstract}

\section{Introduction}

Transport and distribution processes of drugs within biological systems are to a large extent controlled by their lipophilicity. The lipophilicity is one of the crucial parameters included in empirical methods of quantitative structure property relationships (QSPR) and quantitative structure activity relationships (QSAR). ${ }^{1,2}$ Consequently, it is a key parameter in drug design. The usual measure of the lipophilicity of a compound is its partition coefficient, $\log P, 3,4$ which is connected to the standard Gibbs energy of transfer of a compound by the following relation: $\log P=-\Delta G^{\ominus} /(2.3 R T)$. Although $\log P$ of neutral compounds is relatively easy to measure by diverse techniques, until recently only four-electrode electrochemical measurements at an interface between two immiscible electrolyte solutions (ITIES) were a successful tool for measuring the liphophilicity of ionizable compounds. ${ }^{5-9}$ However, inherent properties of the abovementioned technique (i.e., its narrow potential window as a result of the presence of electrolytes in both phases and the nonpolarizability of many organic solvents ${ }^{10,11}$ ) render its wider usage. Almost $70 \%$ of the drugs are ionized under physiological conditions $;{ }^{2}$ however, the determination of the partition data of ions is still not routine work.

The so-called "three-phase electrode" technique introduced recently by one of us ${ }^{12-14}$ has proven to be an efficient tool for precisely assessing the lipophilicity of ionic compounds. ${ }^{15-18}$ On the basis of the concept of electroneutrality, the oxidation of a neutral compound (e.g., decamethylferrocene (dmfc)) dissolved in an organic solvent (water-immiscible) and attached as a droplet to the working electrode (paraffin-impregnated graphite electrode (PIGE)) is a prerequisite for transferring the anions from the aqueous solution (in which the working electrode is immersed) into the organic phase. Because no electrolyte is initially present in the organic phase, the applied potential acts only at the interface where the three phases are in intimate contact. Therefore, the overall reaction can start only at the junction where the three phases (graphite electrode | organic solution $\mid$ aqueous solution) meet (Figure 1), and the reaction advances toward the center of the droplet. ${ }^{19,20}$ In the case of a

* Corresponding author. E-mail: fscholz@uni-greifswald.de. Fax: +49+(0)3834-86 4451. thermodynamically reversible ion transfer, it was shown that the standard potential of ion transfer $\Delta \phi^{\ominus}\left(\Delta \phi^{\ominus}=-\Delta G^{\ominus} / z F\right)$ can be evaluated from the formal potential $E_{\mathrm{c}}{ }^{\prime}$ of the voltammograms representing the coupled electron/ion transfer reaction of dmfc (for details, see refs 12-17):

$$
\begin{gathered}
\operatorname{dmfc}_{(\mathrm{NB})}+\mathrm{X}_{(\mathrm{W})}^{-} \leftrightarrows \mathrm{dmfc}_{(\mathrm{NB})}^{+}+\mathrm{X}_{(\mathrm{NB})}^{-}+\mathrm{e}^{-} \\
E_{\mathrm{c}}^{\theta^{\prime}}=E_{\mathrm{dmfc}_{(\mathrm{NB})}{ }^{+} \mid \mathrm{dmfc}_{(\mathrm{NB})}}+\Delta_{\mathrm{W}}^{\mathrm{NB}} \varphi_{\mathrm{X}^{-}}^{\theta}-\frac{R T}{F} \ln \left(a_{\mathrm{X}^{-}{ }_{(\mathrm{W})}}\right)+ \\
\frac{R T}{F} \ln \left(\frac{a^{*} \mathrm{dmfc}_{(\mathrm{NB})}}{2}\right)
\end{gathered}
$$

So far, we have explored this technique for determining the lipophilicity of a variety of organic and inorganic anions. Moreover, because there are no constrains regarding the polarizability of the interface organic $\mid$ aqueous solution, the three-phase electrode approach has been applied to organic solvents such as $n$-octanol, ${ }^{15}$ nitrobenzene, ${ }^{16,17} R$-menthol, and $S$-menthol. ${ }^{18}$ Using a chiral organic solvent as a matrix for $\mathrm{dmfc}$, we have shown that even quantification between the energies of transfer of the D and L forms of some amino acids can be achieved. ${ }^{18}$

A similar approach for monitoring the simultaneous electron and ion transfer in the case of the oxidation of electroactive ionic liquids has been published by Compton et al. ${ }^{21,22}$ The "thinfilm" method developed by Shi and Anson ${ }^{23-28}$ and applied mainly for studying the kinetic of interfacial electron-transfer reactions fundamentally differs from our technique. Extended comments regarding the principal differences between our approach and Anson's can be found in a recent paper. ${ }^{29}$

The subject of this paper is to study the lipophilicity of anionic forms of di- and oligopeptides by the three-phase electrode approach. Peptides are of exceptional biological importance, and many are regarded as therapeutic reagents. ${ }^{1,30}$ By studying the lipophilicity of peptides, one is certainly concerned with the following questions: (i) How large is the individual contribution of each amino acid to the overall lipophilicity of the peptides? (ii) Is the lipophilicity of one peptide (expressed as $\log P$ or $\Delta G^{\ominus}$ ) a linear function of the number and individual contributions of each amino acid residues in the backbone of that 

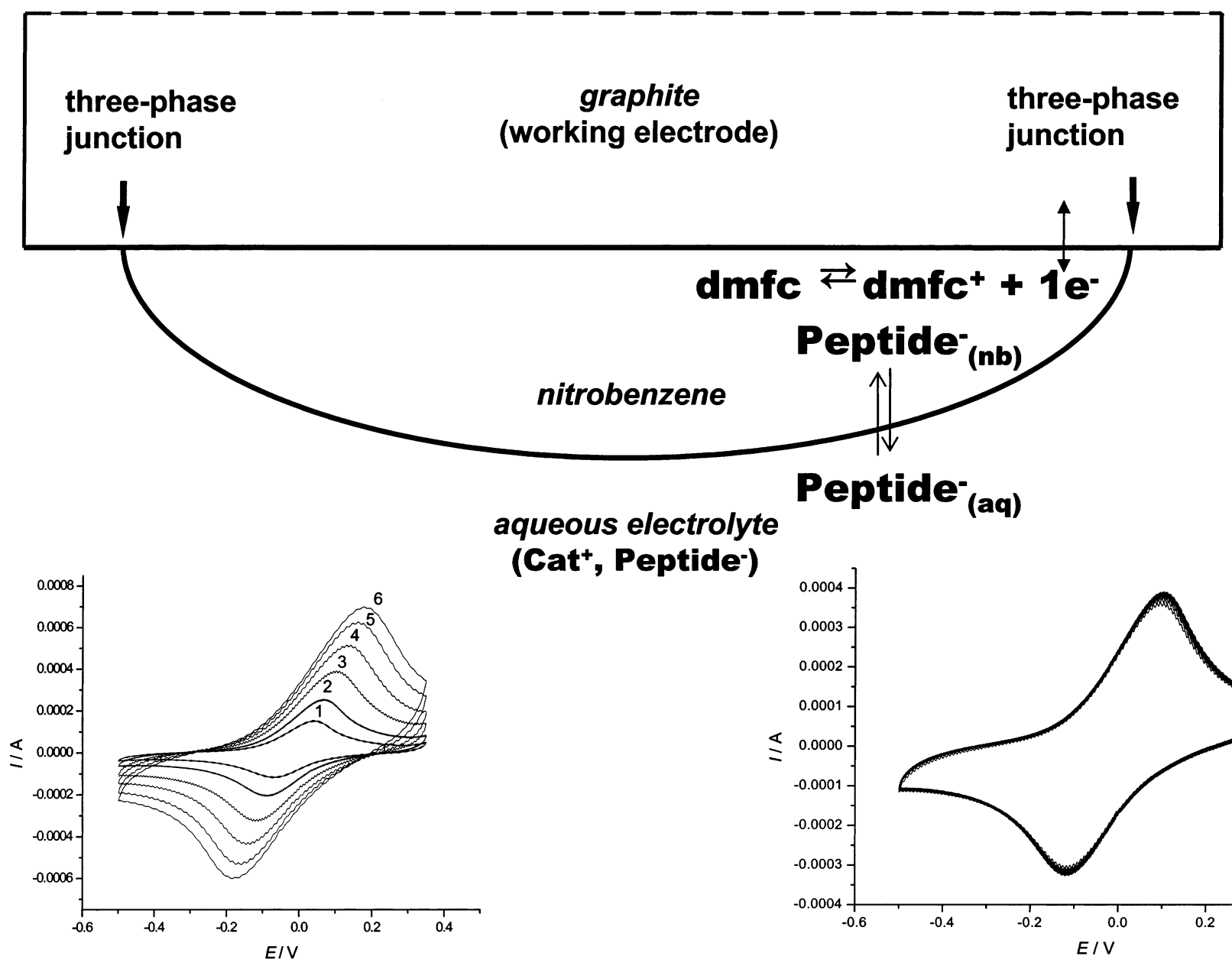

(Cat', Peptide-)

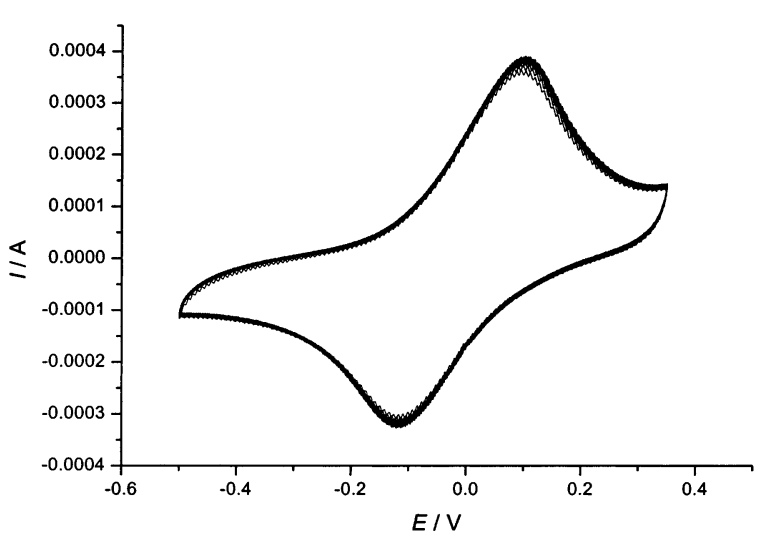

Figure 1. Schematic representation of the simultaneous electron and ion transfer at the three-phase electrode. The inset on the left side shows cyclic voltammograms of the redox process of dmfc at the three-phase electrode followed by transfer of the tripeptide anion Lys-Tyr-Thr ${ }^{-}$. The scan rates are (1) 100 , (2) 200 , (3) 400s, (4) 600, (5) 800 , (6) and $1000 \mathrm{mV} / \mathrm{s}$. The inset on the right side shows consecutive cycling (10 cycles) of the same process recorded with a scan rate of $400 \mathrm{mV} / \mathrm{s}$.

peptide? (iii) How is the lipophilicity of one peptide affected by the position of the amino acid? (iv) Is it possible to evaluate an empirical analytical equation for predicting the lipophilicity of peptides?

At this stage, it is worth mentioning that several lipophilicity (or inverse hydrophobicity) scales have been proposed for neutral amino acids and peptides. ${ }^{31-39}$ A frequently used approach for assessing the lipophilicity of peptides is the development of additive models, whereby the entire lipophilicity of peptides is factored into contributions from molecular fragments (i.e., amino acid residues). Using this approach, Fujita et al. ${ }^{35}$ used a set of $124 \mathrm{di}$ - and tripeptides and tried to investigate whether their $\log P$ values could be calculated from the sum of the liphophilic increments of the amino acid residues. These authors performed highly valuable studies of the liphophilicity of zwiterionic forms of free ${ }^{35}$ and blocked ${ }^{36}$ peptides. Considering the entire liphophilicity of the peptides as a linear function of the "intrinsic" liphophilicities of amino acid constituents as well as of their steric effects and $\beta$-turn potentials, ${ }^{35}$ they found very good correlation between the experimentally determined and calculated liphophilicity data of 124 oligopeptides. Obviously, for an apparently good correlation, they had to take into account additional variables, which made the model rather bulky. Additional statistical analyses of the experimental set of data given by the former authors ${ }^{35,36}$ were performed by Sotomatsu-Niwa et al. ${ }^{37}$ With a relatively simple model in which the steric effects and $\beta$-turn potentials were avoided, Sotomatsu-Niwa et al. ${ }^{37}$ have estimated values for the individual lipophilicity contributions of the amino acid residues that are similar to those reported by Fujita et al. ${ }^{35,36}$ In the same paper, ${ }^{37}$ the authors evaluated an equation for predicting the liphophilicity of free tripeptides in which the position of the amino acid residues was also taken into account. However, only minute influences on the position ( $\mathrm{N}$-terminal or C-terminal) of the amino acid residues caused by the liphophilicity of the peptides were presented. ${ }^{37}$ Testa et al. ${ }^{38}$ have proposed another model for predicting the lipophilicity of peptides, taking into account the molecular volume of peptides and the polarity of the amino acid residues. Assuming the lipophilicity of peptides to be a linear function of the individual contributions and the number of amino acids in the peptides, Lai et al. ${ }^{39}$ have proposed a semiempirical analytical equation for predicting the lipophilicity of peptides. On the basis of the fragment additional or residue additional method, a computer program PLOGP for calculating the $\log P$ of a given peptide has been written by these authors. The analytical equation gives satisfactory results for $\log P$ values of peptides that contain not more than five amino acid residues. Unfortunately, the number of experimental studies on peptide liphophilicity is rather restricted, ${ }^{35,36,38}$ and the majority of the theoretical publications deal with statistical approaches of these sets of data. ${ }^{37,39}$

One great obstacle is always associated with the determination of lipophilicity in partition experiments. In performing the partition experiments either by the classical shaking method or 
SCHEME 1: Scheme of the Voltammetric Microcell Used for Measuring the Liphophilicity of Peptides ${ }^{a}$

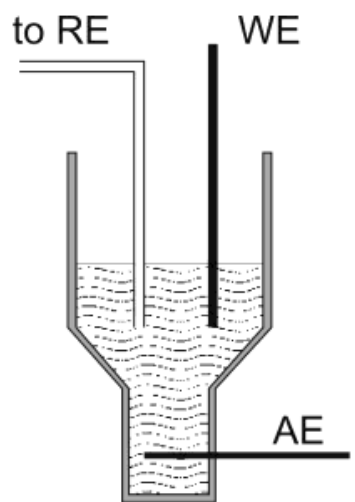

${ }^{a} \mathrm{RE}, \mathrm{WE}$, and $\mathrm{AE}$ stand for reference electrode, working electrode, and auxiliary electrode, respectively.

by partition or centrifugal chromatography, one cannot avoid the mutual miscibility of both water and organic solvents. Therefore, depending on the degree of mutual solubility of the solvents, the concentration of one solute in such a mixture of both solvents differs somewhat more or less significantly from the corresponding one in the pure solvent. Keeping in mind that $\log P$ is defined as the ratio of the equilibrium concentrations of one solute in two pure solvents (i.e., $\log P=\log \left[c_{\mathrm{s}^{-}}\right.$ $\left.(\mathrm{o}) / c_{\mathrm{s}}(\mathrm{w})\right]$, very often the $\log P$ values obtained by partition techniques are very different from the theoretical values for the case of complete immiscibility of the solvents. Interestingly, this phenomenon is significantly underestimated in the literature.

In this paper, an extensive study of the lipophilicity of the anionic forms of di- and oligopeptides has been performed to clarify some of the above-mentioned questions or to approach the answers at least. The electrochemical measurements of the lipophilicity of the anionic forms of these peptides are presented for the first time. The major advantage of the electrochemical measurements over the partition techniques is depicted in the precision of the determined data. It is worth noting that by using the approach of three-phase electrodes we have previously determined standard Gibbs energies of transfer of anions and cations of a large number of amino acids, ${ }^{16}$ and some of these data are recalled in the present paper.

\section{Experimental Section}

All of the used peptides were products of BACHEM (Germany), with purities higher than 99\%. Because the peptides are rather expensive, we designed a special measuring cell capable of operating with a volume of $100 \mu \mathrm{L}$ (cf. Scheme 1). A platinum wire, the counter electrode, was melted into the bottom of a glass cylinder of 2-cm height and 4-mm inner radius. The bottom of the cylinder was drawn out so as to get an inner diameter of only $2 \mathrm{~mm}$. A tube with an inner diameter of 1 $\mathrm{mm}$, filled with a saturated solution of $\mathrm{KCl}$ in agar-agar served as a salt bridge between the reference electrode $(\mathrm{Ag} / \mathrm{AgCl} /$ saturated $\mathrm{KCl}$ ) and the working cell. The working electrode was a paraffin-impregnated graphite electrode $(\mathrm{PIGE})^{41}$ with a radius of about $1 \mathrm{~mm}$. All of the peptides were dissolved in $2 \mathrm{M} \mathrm{NaOH}$ solution. The $\mathrm{pH}$ after the dissolution of the peptides was always above 13, keeping the peptides in the monoanionic form. A 0.1 M solution of decamethylferrocene (ACRÖS, Germany) was prepared by dissolving it in pure nitrobenzene (NB). A droplet of this solution with a volume of $0.5 \mu \mathrm{L}$ was attached to the working electrode (PIGE) and immersed in the aqueous solution of the peptides. Square-wave (SW) and cyclic voltammograms were recorded using the commercial electrochemical measuring system AUTOLAB (PGSTAT 10, Eco-Chemie, Utrecht, Netherlands). Typical instrumental parameters were SW frequency $f=10 \mathrm{~Hz}, \mathrm{SW}$ amplitude $E_{\mathrm{sw}}=50 \mathrm{mV}$, scan increment $\mathrm{d} E=$ $1 \mathrm{mV}$, and starting potential $E_{\mathrm{s}}=-0.55 \mathrm{~V}$ versus $\mathrm{Ag} \mid \mathrm{AgCl}$. For each peptide, the dependencies of the SW peak potentials of SW voltammetric responses of $\mathrm{dmfc}$ on peptide concentration were checked. At least five measurements were made for each concentration, and the average value of the peak potentials was used for calculations. The standard deviation of the peak potentials was $4.60 \mathrm{mV}$, which means that the standard deviation of the determined Gibbs energies of transfer was $0.45 \mathrm{~kJ} / \mathrm{mol}$. In all cases, the slopes of the SW peak potentials versus the logarithm of the peptide concentration were in the range from -45 to $-80 \mathrm{mV}$, which is a good indicator that the entire reaction of $\mathrm{dmfc}$ in NB is followed by the transfer of peptide anions from water to the organic solvent (eq 1). Cyclic voltammetric measurements were performed to check the reversibility of the overall process (at scan rates varying from 50 to $800 \mathrm{mV} / \mathrm{s}$ ). Moreover, consecutive cycling (at least 10 cycles) provided information on the stability of the entire system. All of the estimated values of the standard Gibbs energies of transfer are based on the so-called Grunwald assumption. ${ }^{42}$

\section{Results and Discussion}

A. Determination of the Individual Lipophilic Contribution of Amino Acid Residues to the Lipophilicity of Peptides. All of the data of the lipophilicities of the investigated peptides are presented in Table 1. Representative square-wave voltammograms of the oxidation of dmfc in NB for the three-phase arrangement followed by the transfer of monoanionic forms of Trp-X dipeptides are depicted in Figure 2. Several different series of di- and tripeptides have been explored for the extraction of the so-called "individual lipophilicity contribution" of some amino acids. Shown in Table 2 are the lipophilicity contributions of the amino acid residues (expressed by their $\Delta G$ values) extracted from different series of peptide anions. A negative value of $\Delta G$ means that the presence of that amino acid residue increases the lipophilicity of the corresponding peptide anion compared with the lipophilicity of the amino acid (or peptide) anion that is taken as the "backbone model" for that series. From Table 2, one can see that rather good agreement exists between the set of data of lipophilicity contributions extracted from dipeptide anions Trp- $\mathrm{X}^{-}$and tripeptide anions Leu-Leu- $\mathrm{X}^{-}$and Gly-Phe- $\mathrm{X}^{-}$. Figure $3 \mathrm{~A}$ shows a comparison between the lipophilicity contributions of amino acids in the Trp- $\mathrm{X}^{-}$and Leu-Leu- $\mathrm{X}^{-}$series. These contributions are also in good agreement with the corresponding ones given independently by other authors for the zwitterionic forms (Figure $3 \mathrm{~B}$ and $\mathrm{C}$ ). According to the above set of values for the individual lipophilicity contributions, one can roughly divide the amino acids residues into two groups (i.e., lipophatic and hydrophatic). The first group contains the amino acids that increase the lipophilicity of the peptides (Trp, Phe, Tyr, Leu), whereas the amino acids that increase the hydrophilicity of peptides (Val, Gly, Ala) belong to the latter group. Why the presence of hydrophatic amino acids increases the hydrophilicity of peptides can be understood by considering the following example. By incorporating glycine into the backbone of a peptide, one puts into the new structure two hydrophilic groups $-\mathrm{NH}$ and $-\mathrm{COO}^{-}$and one lipophilic group $\mathrm{CH}_{2}$. In this case, the polarities of the $-\mathrm{NH}_{2}$ and $-\mathrm{COO}^{-}$groups dominate the lipophilic effect produced by the methylene group. The final effect is a stronger hydration of the peptide molecule as a result of a stronger 
TABLE 1: Data of the Lipophilicities of the Investigated Peptides

\begin{tabular}{|c|c|c|c|c|}
\hline peptide anions & $\Delta \phi^{\theta} / \mathrm{V}^{a}$ & $\Delta G^{\theta} / \mathrm{kJ} \mathrm{mol}^{-1 b}$ & $\log P^{\mathrm{c}}$ & $\begin{array}{l}\text { slope } E_{\mathrm{p}} \mathrm{vs} \\
\log [c] / \mathrm{mV}^{d}\end{array}$ \\
\hline \multicolumn{5}{|c|}{ (A) } \\
\hline $\operatorname{Trp}^{-e}$ & 0.115 & 10.80 & -1.90 & -64 \\
\hline Trp-Ala ${ }^{-}$ & 0.165 & 15.75 & -2.75 & -80 \\
\hline Trp-Gly ${ }^{-}$ & 0.162 & 15.60 & -2.73 & -73 \\
\hline Trp-Val ${ }^{-}$ & 0.120 & 11.60 & -2.05 & -75 \\
\hline Trp-Leu ${ }^{-}$ & 0.100 & 9.50 & -1.66 & -73 \\
\hline Trp-Tyr ${ }^{-}$ & 0.075 & 7.40 & -1.30 & -65 \\
\hline Trp-Phe ${ }^{-}$ & 0.055 & 5.30 & -0.93 & -77 \\
\hline Trp-Trp ${ }^{-}$ & 0.05 & 4.80 & -0.85 & -70 \\
\hline Trp-Gly-Gly- & 0.165 & 15.80 & -2.75 & -75 \\
\hline Trp-Gly-Tyr ${ }^{-}$ & 0.155 & 15.00 & -2.65 & -74 \\
\hline Trp-Gly-Gly-Tyr ${ }^{-}$ & 0.160 & 15.50 & -2.70 & -74 \\
\hline \multicolumn{5}{|c|}{ (B) } \\
\hline $\mathrm{Leu}^{-\mathrm{Leu}^{-}}$ & 0.245 & 23.70 & -4.15 & -71 \\
\hline Leu-Leu-Ala ${ }^{-}$ & 0.293 & 28.20 & -4.95 & -57 \\
\hline Leu-Leu-Gly ${ }^{-}$ & 0.290 & 28.00 & -4.91 & -80 \\
\hline Leu-Leu-Leu ${ }^{-}$ & 0.240 & 23.20 & -4.05 & -80 \\
\hline Leu-Leu-Tyr ${ }^{-}$ & 0.205 & 19.70 & -3.45 & -56 \\
\hline Leu-Leu-Phe ${ }^{-}$ & 0.180 & 17.50 & -3.05 & -64 \\
\hline Leu-Gly-Phe & 0.275 & 26.50 & -4.65 & -65 \\
\hline \multicolumn{5}{|c|}{ (C) } \\
\hline Gly-Phe ${ }^{-}$ & 0.260 & 25.00 & -4.40 & -59 \\
\hline Gly-Phe-Ala ${ }^{-}$ & 0.285 & 27.50 & -4.80 & -75 \\
\hline Gly-Phe-Gly ${ }^{-}$ & 0.265 & 25.60 & -4.50 & -63 \\
\hline Gly-Phe-Tyr ${ }^{-}$ & 0.210 & 20.20 & -3.55 & -72 \\
\hline Gly-Phe-Phe ${ }^{-}$ & 0.208 & 20.15 & -3.53 & -70 \\
\hline Phe-Gly-Gly ${ }^{-}$ & 0.300 & 29.00 & -5.10 & -55 \\
\hline \multicolumn{5}{|c|}{ (D) } \\
\hline $\mathrm{Gly}_{-\mathrm{Gly}^{-e}}$ & 0.280 & 27.00 & -4.75 & -49 \\
\hline Gly-Gly-Val- & 0.275 & 26.40 & -4.60 & -57 \\
\hline Gly-Gly-Leu- & 0.280 & 26.80 & -4.70 & -56 \\
\hline Gly-Gly-Tyr ${ }^{-}$ & 0.300 & 29.00 & -5.10 & -57 \\
\hline Gly-Gly-Phe ${ }^{-}$ & 0.270 & 26.00 & -4.55 & -58 \\
\hline Gly-Gly-Trp ${ }^{-}$ & 0.195 & 19.00 & -3.35 & -56 \\
\hline Gly-Leu-Gly ${ }^{-}$ & 0.280 & 27.00 & -4.75 & -49 \\
\hline Gly-Trp-Gly ${ }^{-}$ & 0.165 & 15.80 & -2.75 & -48 \\
\hline Gly-Tyr-Gly ${ }^{-}$ & 0.280 & 27.10 & -4.75 & -48 \\
\hline Gly-Leu-Tyr ${ }^{-}$ & 0.245 & 23.40 & -4.10 & -71 \\
\hline Gly-Leu-Phe ${ }^{-}$ & 0.270 & 26.20 & -4.60 & -60 \\
\hline Gly-Ala-Phe ${ }^{-}$ & 0.285 & 27.40 & -4.80 & -70 \\
\hline \multicolumn{5}{|c|}{ (E) } \\
\hline Tyr-Ala-Gly ${ }^{-}$ & 0.260 & 24.90 & -4.40 & -48 \\
\hline Tyr-Ala-Gly-Phe-Leu ${ }^{-}$ & 0.175 & 16.60 & -2.90 & -50 \\
\hline Tyr-Ala-Gly-Leu-Arg- & 0.175 & 17.10 & -3.00 & -78 \\
\hline Tyr-Ala-Gly-Phe-Met ${ }^{-}$ & 0.190 & 18.40 & -3.30 & -61 \\
\hline Tyr-Ala-Gly-Met-Phe-Glycinol- & 0.260 & 24.90 & -4.40 & -48 \\
\hline Tyr-Lys-Thr ${ }^{-}$ & 0.255 & 24.60 & -4.30 & -59 \\
\hline Lys-Tyr-Thr ${ }^{-}$ & 0.310 & 30.00 & -5.25 & -58 \\
\hline \multicolumn{5}{|c|}{ (F) Amino Acid Anions ${ }^{e}$} \\
\hline $\mathrm{Gly}^{-}$ & 0.275 & 26.60 & -4.65 & -54 \\
\hline $\mathrm{Ala}^{-}$ & 0.285 & 27.50 & -4.80 & -58 \\
\hline $\mathrm{Val}^{-}$ & 0.278 & 26.80 & -4.70 & -52 \\
\hline $\mathrm{Leu}^{-}$ & 0.245 & 23.90 & -4.20 & -66 \\
\hline $\mathrm{Phe}^{-}$ & 0.215 & 21.00 & -3.70 & -60 \\
\hline $\mathrm{Tyr}^{-}$ & 0.220 & 21.20 & -3.72 & -64 \\
\hline Met $^{-}$ & 0.255 & 24.50 & -4.30 & -56 \\
\hline $\operatorname{Trp}^{-}$ & 0.115 & 10.80 & -1.90 & -64 \\
\hline Lys $^{-}$ & 0.283 & 27.30 & -4.78 & -48 \\
\hline $\mathrm{Pro}^{-}$ & 0.305 & 29.50 & -5.20 & -59 \\
\hline $\mathrm{His}^{-}$ & 0.29 & 27.70 & -4.85 & -63 \\
\hline
\end{tabular}

${ }^{a}$ Standard potential differences at the W|NB interface $\left(\Delta \phi^{\theta}\right) .{ }^{b}$ Standard Gibbs energies of ion transfer $\left(\Delta G^{\theta}\right) .{ }^{c}$ Logarithm of the ion partition coefficients $(\log P) .{ }^{d}$ Slopes of the dependencies of the peak potentials vs logarithm of the concentration of peptide anions in the water phase $\left(E_{\mathrm{p}}\right.$ vs $\log [c])$ evaluated from the square-wave voltammetric responses of $\mathrm{dmfc}$ at the three-phase electrode. ${ }^{e}$ Data taken from ref 16.

interaction between the water molecules and the polar groups. Consequently, the overall energy of transfer, which is defined as a difference between the solvation energies of one solute between two different solvents, increases.

The set of lipophilicity contributions of amino acid residues in the series of Gly-Gly-X tripeptides differs in some cases significantly from the corresponding ones in other series.

B. Is the Lipophilicity of a Peptide an Additive Linear Function of the Individual Lipophilicity Contributions of its Amino Acid Residues? As we noted previously, a frequently 

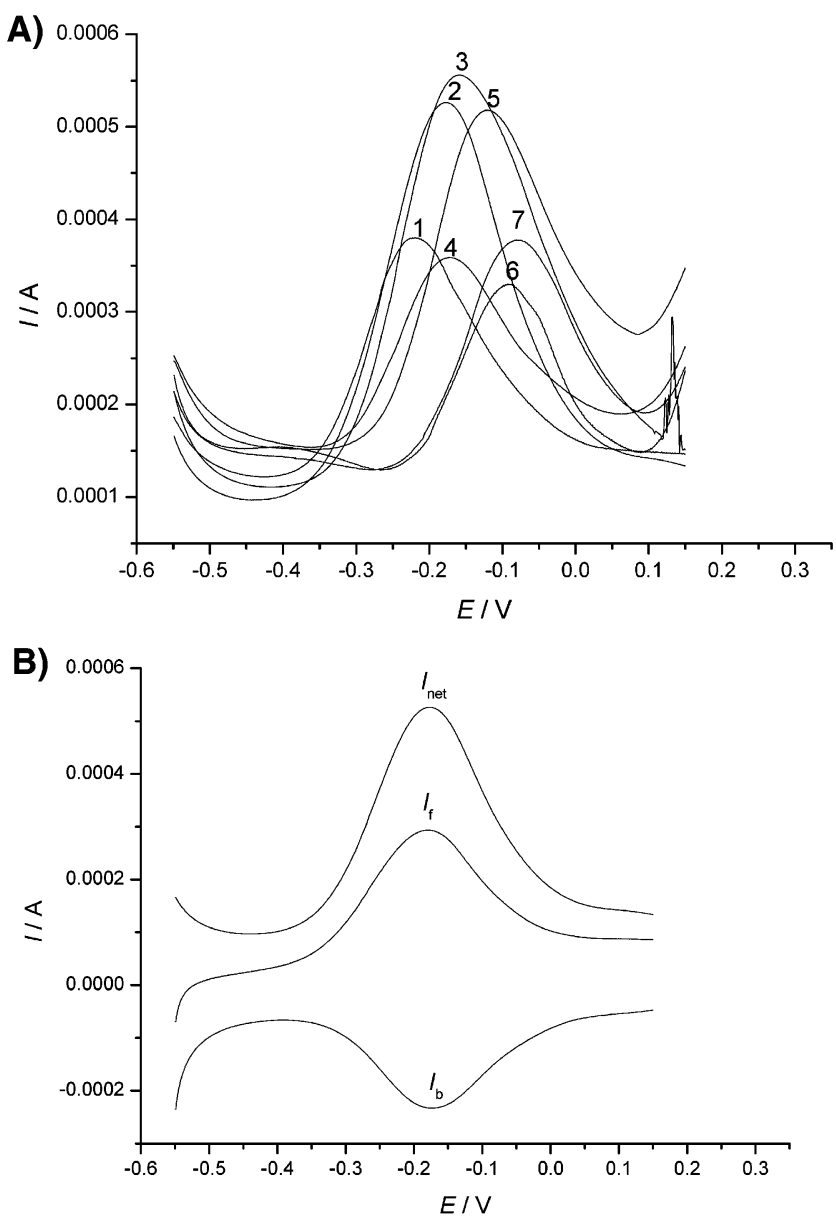

Figure 2. (A) Square-wave voltammetric responses of dmfc at a threephase electrode followed by transfer of the monoanionic forms of the following dipeptides: (1) $1 \mathrm{M}$ Trp-Phe ${ }^{-}$, (2) $0.7 \mathrm{M} \mathrm{Trp}-\mathrm{Tyr}^{-}$, (3) 0.7 M Trp-Leu ${ }^{-}$, (4) 0.5 M Trp-Trp ${ }^{-}$, (5) 0.7 M Trp-Val-, (6) 0.7 M TrpGly $^{-}$, and (7) $0.7 \mathrm{M}$ Trp-Ala $^{-}$. (B) Forward, backward, and net components of the square-wave voltammetric response of $\mathrm{dmfc}$ at the three-phase electrode followed by transfer of the anionic form of dipeptide Trp-Tyr ${ }^{-}$. All of the experimental and instrumental conditions are given in the Experimental Section.

used approach for assessing the lipophilicity of peptides is the development of additive models, whereby the entire lipophilicity of a peptide is factorized into contributions from molecular fragments of amino acids. Shown in Table 1A and E are several examples by which we wanted to test whether the lipophilicity of peptide anions is really an additive function of the individual lipophilic contributions of the amino acid residues. From the examples given in Table $1 \mathrm{~A}$ and $\mathrm{E}$, one can see that the assumption that the lipophilicity of the peptides is a simple sum of the contributions of the amino acid residues failed in all cases. For example, the addition of one glycine residue to the backbone of the dipeptide anion Trp-Gly ${ }^{-}$increases the lipophilicity of the new Trp-Gly-Gly ${ }^{-}$tripeptide anion by $0.2 \mathrm{~kJ} / \mathrm{mol}$ and not by $4.8 \mathrm{~kJ} / \mathrm{mol}$, which would apply if one assumes that the lipophilicity of the peptide is an additive function. The case when one glycine residue is added to the backbone of the tripeptide anion Trp-Gly-Tyr ${ }^{-}$is similar. Even more obvious is the failing of the additivity assumption in the case of the four- and polypeptide anions in Table 1E. In all of the presented cases, the lipophilicity of peptide anions is higher than expected assuming an additive function of the individual amino acid contributions.

One of the reasons for such behavior of peptides is probably their folding. ${ }^{2,40}$ The importance of folding increases with the length of the peptide chain. Generally, folding will increase the lipophilicity because of the intramolecular interaction of the polar groups and especially also because of intramolecular hydrogen bonding. These phenomena are very significant, especially for the anions, because the effect of charge delocalization plays a pronounced role in the lipophilicity of charged species. These effects are probably the major reason for the failure of all models to predict the lipophilicity of peptides by additive methods. ${ }^{35-37,39}$ In some cases, such effects forced the authors to propose separate models to estimate the lipophilicity of different classes (di-, tri-, tetra-, and penta-) of peptides. ${ }^{38}$ Shown in Figure 4 is a comparison between the $\Delta G^{\ominus}$ values of amino acid anions and $\operatorname{Trp}-\mathrm{X}^{-}$dipeptide anions. A nonlinear dependence between both sets of data is observed. The last can serve as additional proof that the lipophilicity of one peptide cannot be approximated by a simple additive function of the individual lipophilic contributions of their amino acid residues.

C. How is the Lipophilicity of the Peptides Affected by the Position of the Amino Acid Residues? In almost all of the models proposed to assess the lipophilicity of peptides, the authors assumed an independence of the lipophilicity of the peptides on the position of the amino acid residues. ${ }^{33-39}$ A study of this question is certainly very important. For this purpose, we have explored several couples of different tripeptides in which the positions of both amino acid residues were exchanged (Table 3). It is worth pointing out that the influence of exchanging the amino acid residues in the $1-2$ as well as in $2-3$ positions of peptides was studied ( 1 is the $\mathrm{N}$-terminal, and 3 is the $\mathrm{C}$ terminal). One can see that in most of the cases there are no differences in the $\Delta G$ values by exchanging positions 1 and 2. However, for couples Gly-Trp-Gly ${ }^{-}$and Gly-Gly-Trp ${ }^{-}$ and Gly-Tyr-Gly ${ }^{-}$and Gly-Gly-Tyr ${ }^{-}$(i.e., exchanging positions 2 and 3), differences of 3.2 and $2 \mathrm{~kJ} / \mathrm{mol}$ have been observed, respectively. Even more obvious differences exist for couples Tyr-Lys-Thr ${ }^{-}$and Lys-Tyr-Thr ${ }^{-}$and Phe-Gly-Gly ${ }^{-}$and GlyPhe-Gly ${ }^{-}$(i.e., 5.40 and $3.40 \mathrm{~kJ} / \mathrm{mol}$, respectively). In all cases, a higher lipophilicity results when the lipophilic amino acid residue is placed at position 2. Most likely, the presence of

TABLE 2: Individual Lipophilicity Contributions of the Amino Acid Residues in Different Classes of Peptides

\begin{tabular}{lccccrr}
\hline $\begin{array}{c}\text { amino acid } \\
\text { residue }\end{array}$ & $\begin{array}{c}\Delta G \text { contribution } \\
\mathrm{kJ} \mathrm{mol}^{-1}\end{array}$ & $\begin{array}{c}\Delta G \text { contribution } \\
\mathrm{kJ} \mathrm{mol}^{-1}\end{array}$ & $\begin{array}{c}\Delta G \text { contribution } \\
\mathrm{kJ} \mathrm{mol}^{-1}\end{array}$ & $\begin{array}{c}\Delta G \text { contribution } \\
\mathrm{kJ} \mathrm{mol}^{-1}\end{array}$ & $\begin{array}{c}\Delta G \text { contribution } \\
\mathrm{kJ} \mathrm{mol}^{-1}\end{array}$ & $\begin{array}{c}\Delta G \text { contribution } \\
\mathrm{kJ} \mathrm{mol}^{-1}\end{array}$ \\
\hline Trp & -6.00 & & & -8.00 & -3.60 & -3.40 \\
Phe & -5.50 & -6.20 & -4.85 & -1.00 & -2.90 & -2.50 \\
Tyr & -3.40 & -4.00 & -4.80 & 2.00 & -1.40 & -2.30 \\
Leu & -1.30 & -0.50 & & -0.20 & -1.90 & -1.80 \\
Val & 0.80 & & & -0.60 & -0.80 & -1.50 \\
Gly & 4.80 & 4.30 & 0.60 & 0.40 & 0.55 & -0.00 \\
Ala & 4.95 & 4.50 & 2.50 & & 0.68 & -0.50
\end{tabular}

${ }^{a}$ Estimated as the difference $\Delta G^{\ominus}\left(\operatorname{Trp}-\mathrm{X}^{-}\right)-\Delta G^{\ominus}\left(\operatorname{Trp}^{-}\right) .{ }^{b}$ Estimated as the difference $\Delta G^{\ominus}\left(\right.$ Leu-Leu-X $\left.{ }^{-}\right)-\Delta G^{\ominus}\left(\right.$ Leu-Leu $\left.{ }^{-}\right) .{ }^{c}$ Estimated as the difference $\Delta G^{\ominus}\left(\right.$ Gly-Phe- $\left.\mathrm{X}^{-}\right)-\Delta G^{\ominus}\left(\right.$ Gly-Phe $\left.{ }^{-}\right)$. ${ }^{d}$ Estimated as the difference $\Delta G^{\ominus}\left(\right.$ Gly-Gly-X $\left.{ }^{-}\right)-\Delta G^{\ominus}\left(\right.$ Gly-Gly $\left.^{-}\right)$. ${ }^{e}$ Taken from ref 39 for the zwitterionic form. ${ }^{f}$ Taken from ref 33 for the zwitterionic form. 

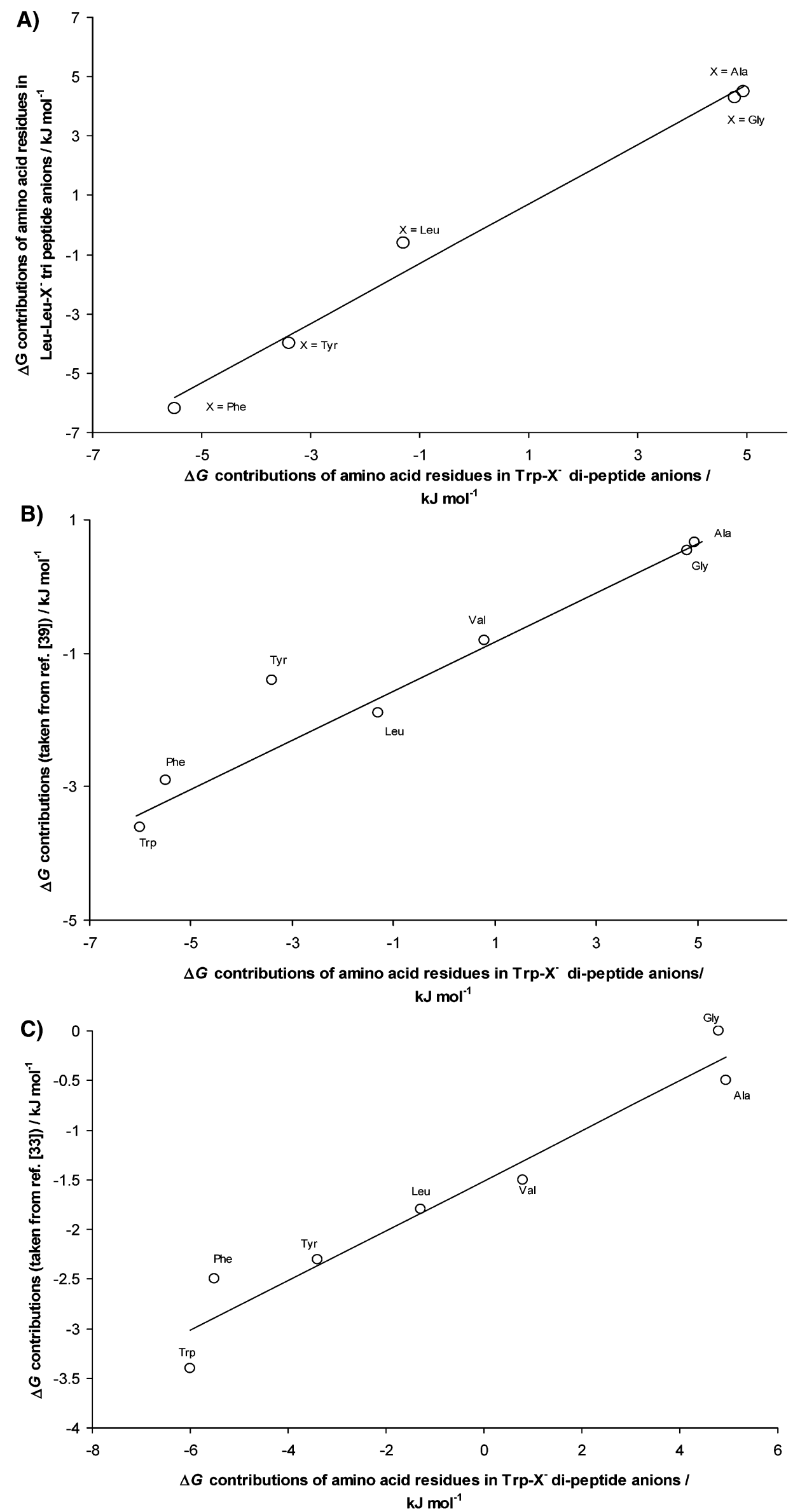

Figure 3. (A) Comparison between the individual lipophilicity contributions of the amino acid residues for different classes of peptide anions. (B and C) Comparison between our experimental data and literature data for zwitterionc forms of the amino acids. 


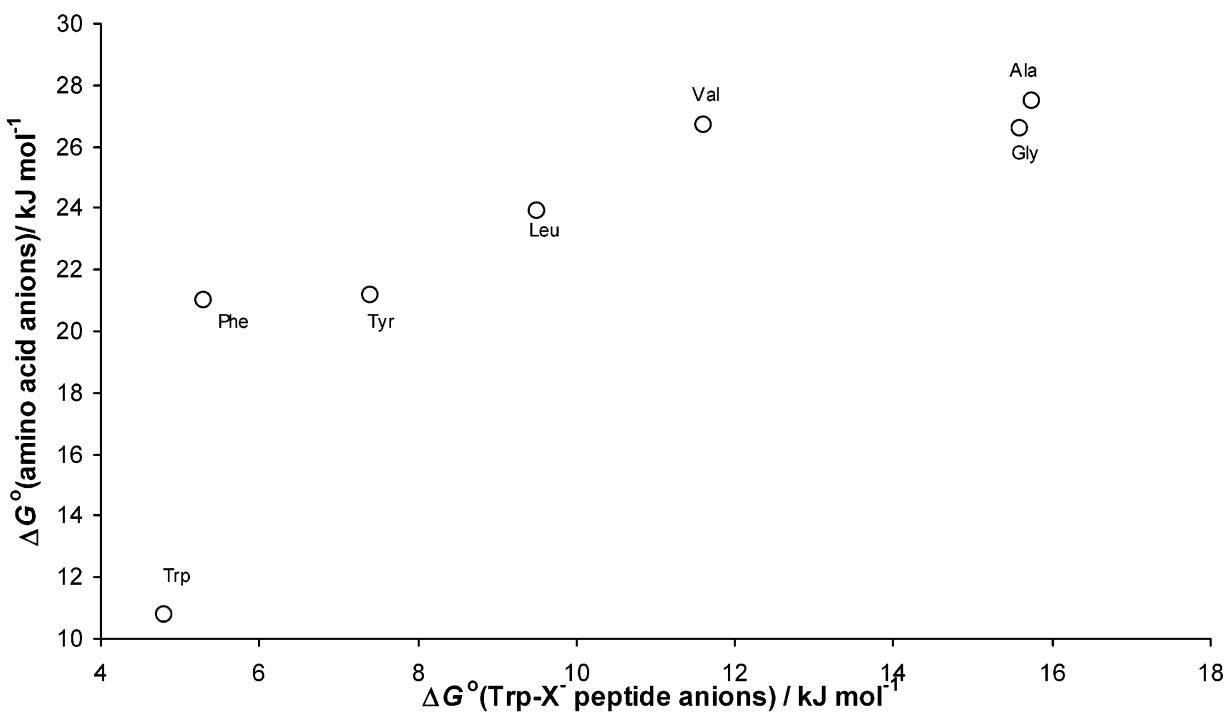

Figure 4. Comparison between the standard Gibbs energies of transfer of anions of amino acids and anions of dipeptides Trp- $\mathrm{X}^{-}(\mathrm{X}=\mathrm{Trp}$, Phe, Tyr, Leu, Val, Gly, and Ala). The data for standard Gibbs energies of transfer of amino acid anions are taken from ref 16.

TABLE 3: Influence of the Positions of the Amino Acid Residues on the Standard Gibbs Energies of Transfer of Different Tripeptides

\begin{tabular}{|c|c|c|}
\hline peptide anions & $\begin{array}{c}\Delta G^{\theta} / \\
\mathrm{kJ} \mathrm{mol}^{-1}\end{array}$ & $\begin{array}{l}\Delta\left(\Delta G^{\theta}\right) / \\
\mathrm{kJ} \mathrm{mol}^{-1}\end{array}$ \\
\hline $\begin{array}{l}\text { Gly-Phe-Ala } \\
\text { Gly-Ala-Phe }\end{array}$ & $\begin{array}{l}27.50 \\
27.40\end{array}$ & 0.10 \\
\hline $\begin{array}{l}\text { Gly-Gly-Phe }{ }^{-} \\
\text {Gly-Phe-Gly }\end{array}$ & $\begin{array}{l}26.00 \\
25.60\end{array}$ & 0.40 \\
\hline $\begin{array}{l}\text { Gly-Gly-Leu- } \\
\text { Gly-Leu-Gly }\end{array}$ & $\begin{array}{l}26.80 \\
27.00\end{array}$ & 0.20 \\
\hline $\begin{array}{l}\text { Gly-Gly-Tyr } \\
\text { Gly-Tyr-Gly }\end{array}$ & $\begin{array}{l}29.00 \\
27.10\end{array}$ & 1.90 \\
\hline $\begin{array}{l}\text { Gly-Gly-Trpp } \\
\text { Gly-Trp-Gly }\end{array}$ & $\begin{array}{l}19.00 \\
15.80\end{array}$ & 3.20 \\
\hline $\begin{array}{l}\text { Gly-Trp-Gly } \\
\text { Trp-Gly-Gly }\end{array}$ & $\begin{array}{l}15.80 \\
15.80\end{array}$ & 0 \\
\hline $\begin{array}{l}\text { Leu-Gly-Phe } \\
\text { Gly-Leu-Phe }\end{array}$ & $\begin{array}{l}26.50 \\
26.20\end{array}$ & 0.30 \\
\hline $\begin{array}{l}\text { Phe-Gly-Gly- } \\
\text { Gly-Phe-Gly }\end{array}$ & $\begin{array}{l}29.00 \\
25.60\end{array}$ & 3.40 \\
\hline $\begin{array}{l}\text { Lys-Tyr-Thr- } \\
\text { Tyr-Lys-Thr }\end{array}$ & $\begin{array}{l}24.60 \\
30.00\end{array}$ & 5.40 \\
\hline
\end{tabular}

aromatic amino acid residues (Trp, Phe, and Tyr) at position 2 produces a significant delocalization of the negative charge of the $\mathrm{COO}^{-}$group of the glycine residues. As a consequence of such charge delocalization, the water-peptide interactions become weaker. Therefore, the corresponding peptides will have a higher lipophilicity. These examples show that the position of the amino acid residues may in some cases have a significant influence on the lipophilicity of the peptides.

\section{Conclusions}

In this paper, we have studied the lipophilicity of the anionic forms of different classes of peptides by the three-phase electrode technique. Major attention was focused on determining the contributions of the amino acid residues to the overall lipophilicity of different oligopeptide anions. We have shown that it is rather unreasonable to approximate the entire lipophilicity of the peptide anions as an additive function of the contributions of their amino acid residues. Furthermore, the effect of the position of the amino acid residues in the chain of the peptides is not trivial and in some cases produces significant differences in the lipophilicity of peptides. Bearing in mind that the folding of peptides will also influence the lipophilicity of the peptides, one can assume that only a complete molecular modeling of the peptide structure and solvation may allow lipophilicities to be calculated. Because such comprehensive theoretical studies are hardly to be expected in the near future, extended experimental work is necessary to unravel the influence of the nature of an amino acid and its position on the lipophilicity of a peptide. On the basis of the results presented here, we plead for establishing a framework of experimentally determined contributions of single amino acids that also takes into account the position of the amino acid in the peptide. With the electrochemical technique used in this study, such systematic determinations are feasible. Of course, the secondary and tertiary structures of a peptide, which themselves result partially from the lipophilicities of peptide fragments, finally influence the overall lipophilicity of a peptide. Systematic studies of the effect of the position of an amino acid residue in the peptide will also contribute to the calculation of the lipohilicities of such peptide fragments.

Acknowledgment. F.S. acknowledges support by the Deutsche Forschungemeinschaft (DFG) and the Fonds der Chemischen Industrie (FCI). R.G. thanks the Deutscher Akademischer Austauschdienst (DAAD) for the provision of a Ph.D. scholarship. We thank Professor Klaus Weisz for discussions.

\section{References and Notes}

(1) Plass, M. Habilitation Thesis, Martin Luther University, HalleWittenberg, Germany, 2000; Chapters 1 and 2.

(2) Testa, B.; van de Waterbeemd, H.; Folkers; G.; Gay, R. Pharmacokinetic Optimization in Drug Research; Wiley-WCH: Weinheim, Germany, 2001; Chapter 6, pp 591-613.

(3) Reymond, F.; Steyaert, G.; Carrupt, P.-A.; Testa, B.; Girault, H. H. J. Am. Chem. Soc. 1996, 118, 11951.

(4) . Testa, B.; van de Waterbeemd, H.; Folkers, G.; Gay, R. Pharmacokinetic Optimization in Drug Research; Wiley-WCH: Weinheim, Germany, 2001; Chapter 6, pp 275-304.

(5) Girault, H. H.; Schiffrin, D. J. Electroanalytical Chemistry: A Series of Advances; Bard, A. J., Ed.; Marcel Dekker: New York, 2000; Vol. 15, pp $1-132$.

(6) Reymond, F.; Carrupt, P. A.; Girault, H. H. J. Electroanal. Chem. 2000, 449, 49. 
(7) Reymond, F.; Fermin, D.; Lee, H. J.; Girault, H. H. Electrochim. Acta 2000, 45, 2647.

(8) Bouchard, G.; Carrupt, P.-A.; Testa, B.; Gobry, V.; Girault, H. H. Chem.-Eur. J. 2002, 8, 3478.

(9) Chopineaux-Courtois, V.; Reymond, F.; Bouchard, G.; Carrupt, P.A.; Testa, B.; Girault, H. H. J. Am. Chem. Soc. 1999, 121, 1743.

(10) Marcus, Y. Ion Properties; Marcel Dekker: New York, 1997; pp 212-219.

(11) Volkov, A. G. Liquid Interfaces in Chemical, Biological and Pharmaceutical Applications; Marcel Dekker: New York, 2001; Vol. 95, Chapter 3, pp 729-773.

(12) Scholz, F.; Komorsky-Lovrić, Š.; Lovrić, M. Electrochem. Commun. 2000, $2,112$.

(13) Komorsky-Lovrić, Š.; Lovrić, M.; Scholz, F. J. Electroanal. Chem. 2001, 508, 129.

(14) Komorsky-Lovrić, S.; Lovrić, M.; Scholz, F. Collect. Czech. Chem. Commun. 2001, 66, 434.

(15) Gulaboski, R.; Mirčeski, V.; Scholz, F. Electrochem. Commun. $\mathbf{2 0 0 2}, 4,277$.

(16) Gulaboski, R.; Mirčeski, V.; Scholz, F. Amino Acids 2003, 24, 149.

(17) Komorsky-Lovrić, S.; Riedl, K.; Gulaboski, R.; Mirčeski, V.; Scholz, F. Langmuir 2002, 18, 3090; 2002, 18, 8000.

(18) Scholz, F.; Gulaboski, R.; Mirčeski, V.; Langer, P. Electrochem. Commun. 2002, 4, 659 .

(19) Donten, M.; Stojek, Z.; Scholz, F. Electrochem. Commun. 2002 4,324 .

(20) Tasakorn, P.; Chen, J.; Aoki, K. J. Electroanal. Chem. 2002, 533, 119.

(21) Schröder, U.; Compton, R. G.; Marken, F.; Bull, S. D.; Davies, S. G.; Gilmour, S. J. Phys. Chem. B 2001, 105, 1344.

(22) Schröder, U.; Wadhawan, J.; Evans, R. G.; Compton, R. G.; Wood, B.; Walton, D. J.; France, R. R.; Marken, F.; Bulman Page, P. C.; Hayman, C. M. J. Phys. Chem. B 2002, 106, 8697.
(23) Shi, C.; Anson, F. C. Anal. Chem. 1998, 70, 3114.

(24) Shi, C.; Anson, F. C. J. Phys. Chem. B 1998, 102, 9850.

(25) Shi, C.; Anson, F. C. J. Phys. Chem. B 1999, 103, 6283

(26) Chung, T. D.; Anson, F. C. Anal. Chem. 2001, 73, 337.

(27) Shi, C.; Anson, F. C. J. Phys. Chem. B 2001, 105, 1047.

(28) Shi, C.; Anson, F. C. J. Phys. Chem. B 2001, 105, 8963.

(29) Gulaboski, R.; Riedl, K.; Scholz, F. Phys. Chem. Chem. Phys. 2003, $5,1284$.

(30) Testa, B.; van de Waterbeemd, H.; Folkers, G.; Gay, R. Pharmacokinetic Optimization in Drug Research; Wiley-WCH: Weinheim, Germany, 2001; Chapter 3, pp 117-153.

(31) Takeda, Y.; Ezaki, T.; Kudo, Y.; Matsuda, H. Bull. Chem. Soc. Jpn. 1995, 68, 787.

(32) Testa, B.; Raynaud, I.; Kier, L. B. Helv. Chim. Acta 1999, 82, 657. 3824 .

(34) Kyte, J.; Doolittle, R. F. J. Mol. Biol. 1982, 157, 105.

(35) Akamatsu, M.; Fujita, T. J. Pharm. Sci. 1992, 81, 164.

(36) Akamatsu, M.; Katayama, T.; Kishimoto, D.; Kurokawa, Y.; Shibata, H.; Ueno, T.; Fujita, T. J. Pharm. Sci. 1994, 83, 1026.

(37) Sotomatsu-Niwa, T.; Ogino, A. J. Mol. Model. 1997, 392, 43.

(38) Vallat, P.; Gaillard, P.; Carrupt, P.-A.; Tsai, R.-S.; Testa, B. Helv. Chim. Acta 1995, 78, 471.

(39) Tao, P.; Wang, R.; Lai, L. J. Mol. Model. 1999, 5, 189.

(40) Chou, Y. P.; Fasman, G. D. J. Mol. Biol. 1977, 115, 135.

(41) Scholz, F.; Meyer, B. Electroanalytical Chemistry: A Series of Advances; Bard, A. J., Rubinstein, I., Eds.; Marcel Dekker: New York, 1998; Vol. 20, pp 1-82.

(42) Grunwald, E.; Baughman, G.; Kohnstam, G. J. Am. Chem. Soc. 1969, 82,5801 